【原著】

\title{
神経難病患者・介護者における補完代替医療利用の実態調査 Use of Complementary and Alternative Medicine by Intractable Neurodegenerative Patients and Caregivers
}

紀平為子 ${ }^{1, *}$, 岡本和士 ${ }^{2}$, 吉田宗平 ${ }^{1}$, 若山育郎 1 , 吉備 登 $^{3}$ Tameko KIHIRA ${ }^{1, *}$, Kazushi OKAMOTO ${ }^{2}$, Sohei YOSHIDA ${ }^{1}$, Ikuro WAKAYAMA ${ }^{1}$, Noboru $\mathrm{KIBI}^{3}$

1 関西医療大学保健医療学部神経内科

2 愛知県立大学看護学部公衆衛生学

3 関西医療大学保健医療学部鍼炎学科

\section{【要 旨】}

神経難病患者における補完代替医療 (CAM) の利用に関する実態調査の報告は極めて少な い. 本研究の目的は, 神経難病患者の CAM 利用の実態を把握し今後の難病療養の基礎資 料として役立てることである．対象は，和歌 山県内の筋萎縮性側索硬化症，パーキンソン 病と関連疾患, 春䯣小脳変性症, スモン患者 1,406 名と，介護者（対照）とした.あんま． マッサージ・指圧, 鍼炎, 柔道整復, 漢方, 健康補助食品について質問票を郵送し，無記 名回答で回収した．回収率は患者 $33.7 \%$ ，対 照 30\%で，回収率から求めた CAM 利用割合 は，神経難病患者 $20.5 \%$ ，対照 $9.8 \%$ であっ た.「あんま・マッサージ・指圧」が神経難病 患者に最も利用されており, 利用患者の 51.3 \%が「痛みの軽減や動きの改善などに効果あ り」と回答した，本療法は対照でも $32.4 \%$ で 利用され，その $62.8 \%$ で効果ありとされた. 効果ありと回答した神経難病患者および対照 では主観的健康感が良好である者が有意に多 かった．根治療法が未だない疾患を有する患 者と介護者において療養生活上での症状や心 身の負担軽减に対して CAM 利用が選択肢の 一つとして有用と考えられた。

【キーワード】

神経変性疾患患者, パーキンソン病, 利用頻 度, 効果, 介護者
はじめに

補完代替医療 (CAM) は西洋現代医学領域以外の全て の医療の総称で，一般的に毒性や侵襲性の低い治療法と の印象があるため日常的に受け入れられやすい傾向があ る. Eisenberg らは，アメリカ国民の CAM 利用率は42.1 $\%$ ，一方日本では $65.6 \%$ と報告している1)。神経難病を 有し療養中の患者では，現代医療と併用して症状緩和の ためCAMを利用する機会が増加していると推察され る。しかしながら，我々の渉猟した限り神経難病患者に おける CAM 利用の実態に関する報告は極めて少ない. 本研究は，CAM 利用の実態と効果に関する利用者の評 価を把握し，今後の神経難病療養上での CAM の有用性 を考える基礎資料として役立てる事を目的とした

\section{方法}

和歌山県内の厚生労働科学省難治性疾患克服研究事業 で指定されている特定疾患のらち，筋萎縮性側索硬化症 96 名，パーキンソン病 1,048 名，パーキンソン病関連疾 患（多系統萎縮症，進行性核上性麻痺，大脳皮質基底核 変性症） 89 名，春髄小脳変性症 155 名，スモン 18 名の 患者，計 1,406 名と対照として健常な介護者もしくは患 者の家族 1,406 名を本研究の対象とした。本研究では CAM として「あんま・マッサージ・指圧」，「鍼尒」，「柔

受理日：2010 年 8 月 23 日

* 干590-0482 大阪府泉南郡熊取町若葉 2-11-1 関西医療大学保健医療学部 Tel: 072-453-8251 Fax: 072-453-0276 E-mail: tkihira815@kansai.ac.jp 
道整復 (接骨) 」, 「漢方 (医院や薬局で処方されるもの) 」, 「健康補助食品」について調査した. 質問票には 1) 年齢, 2) 性別, 3) 疾患名, 4) 介護度, 5) 日常生活の状況（1 : 仕事や家事ができる，2：近所までの外出は一人ででき る，3:身の回りのことは一人でできる，4：身の回りの ことに介助が必要， 5 : 寝たり起きたり，6：座れるが主 として寝たきり，7：胃瘦造設している，8：呼吸器を使 用している)，6) 現在の全般的な健康状態（1：療養中で あるが病状は落ち着いて扣り, 気分は良い, 2 : 療養中で あるが，気分はまあまあ良い， $3:$ 全般的にあまり良くな い, 4: 良くない)，7)一年前と比べて日常生活の状況の 変化（漠然とした体の不調, 病状の進行, それぞれにつ いて 1 : 増えた（悪くなった，2：変わらない， 3 : 減っ た（良くなった），8）最近一年間で利用した補完代替医 療について（利用した補完代替医療の種類, 頻度, 効果 (1：あり，2：なし，3: 不明)，9) 効果の内容，10) 補完 代替医療を利用するに際して主治医に相談したか，など の質問項目，全 10 問とした. 本アンケート用紙を郵送法 にて患者宅に送付し，回答は個人情報保護のため無記名 とし返信用封筒にて回収した. 患者住所は, 和歌山県庁 福祉保健部健康局難病 - 感染症対策課から「特定疾患治 療研究事業に抢海臨床調查個人票の研究目的使用に関 する要綱」に基づき住所ラベルの提供を受けた．調査期 間は平成 20 年 6 月 1 日から同年 8 月 31 日とした。本研 究は平成 20 年度関西医療大学倫理審査会で承認された。

\section{結果}

\section{I. 神経難病患者の CAM 利用実態について}

全対象者のらち, 神経難病患者では $33.7 \%$ から，対照 では 30.2\%から有効回答が得られた．回答した患者と対 照の属性と日常生活状況を表 1 亿示した。患者と対照の 男女比に有意差を認めなかった．患者の平均年齢は対照 のそれより有意に高齢であった，疾患別ではパーキンソ ン病が $62.5 \%$ と最も多く, 次いで春䯣小脳変性症, パーキ ンソン病関連疾患，ALS がそれぞれ 10\%前後であった。 患者の日常生活状況については，身の回りのことに介助 を要する者が $44.1 \%$ と最も多く, 次いで寝たり起きたり， あるいは座れるが主として寝たきりの者が約 $20 \%$, 胃瘦 造設 $11.4 \%$, 呼吸器使用 7.4\%の順であった. 患者の介護 度は，要支援（社会的支援を要する）と要介護度 1 また は2（部分的か軽度の介護を要する）の患者を合わせて $50.2 \%$ ，他は要介護 3 以上であった．患者では，現在の 健康状態について「良い」,「まあまあ良い」と回答した 者は $55.3 \%$ ，「あまり良くない」「良くない」が44.6\%で あった。
表 1 回答した患者と介護者の属性と日常生活状況

\begin{tabular}{|c|c|c|c|}
\hline & & 患者（\%） & 対照（\%) \\
\hline \multicolumn{2}{|c|}{ 回収率 } & 33.7 & 30.2 \\
\hline \multirow[t]{7}{*}{ 年齢 } & 男性 (Mean \pm S.D.) & \multicolumn{2}{|c|}{$69.1 \pm 11.3$ 歳 $64.8 \pm 14.1$ 歳 } \\
\hline & 女性 & \multicolumn{2}{|c|}{$72.4 \pm 10.4$ 歳 $61.7 \pm 13.7$ 歳 } \\
\hline & $<50$ & 4 & 12.7 \\
\hline & $50-59$ & 10.5 & 23.6 \\
\hline & $60-69$ & 22.5 & 28.8 \\
\hline & $70-79$ & 37.7 & 28.4 \\
\hline & 80 歳以上 & 22.3 & 6.5 \\
\hline \multirow[t]{2}{*}{ 性 } & 男性 & 43.9 & 36.2 \\
\hline & 女性 & 56.1 & 63.8 \\
\hline \multicolumn{4}{|c|}{ 特定疾患の病名 } \\
\hline & パーキンソン病 & 62.5 & \\
\hline & 脊髄小脳変性症 & 12.8 & \\
\hline & パーキンソン病関連疾患 & 9.6 & \\
\hline & 筋萎縮性側索硬化症 & 8.6 & \\
\hline & スモン & 1.6 & \\
\hline & その他 & 1.4 & \\
\hline \multicolumn{4}{|c|}{ 日常生活状況（複数回答可） } \\
\hline & 仕事や家事ができる & 17.6 & \\
\hline & 近所まで外出は一人でできる & 27.3 & \\
\hline & 身の回りのことは一人でできる & 37.6 & \\
\hline & 身の回りのことに介助が必要 & 44.1 & \\
\hline & 寝たり起きたり & 19.3 & \\
\hline & 座れるが主として寝たきり & 17.3 & \\
\hline & 胃瘻を造設している & 11.4 & \\
\hline & 呼吸器を使用している & 7.4 & \\
\hline \multicolumn{4}{|c|}{ 患者の介護度 } \\
\hline & 要支援 & 17 & \\
\hline & 要介護度 1 & 11.6 & \\
\hline & 要介護度 2 & 21.6 & \\
\hline & 要介護度 3 & 12.8 & \\
\hline & 要介護度 4 & 10.9 & \\
\hline & 要介護度 5 & 26.1 & \\
\hline \multicolumn{4}{|c|}{ 主観的健康状態 } \\
\hline & 良い & 17.2 & 6.5 \\
\hline & まあまあ良い & 38.1 & 56.5 \\
\hline & あまり良くない & 37.5 & 30.7 \\
\hline & 良くない & 7.1 & 6.3 \\
\hline
\end{tabular}

神経難病患者の CAM 利用実態を把握するため, 月 1 回以上利用する $\mathrm{CAM}$ の利用割合を表 2 飞, 疾患別の CAM 利用頻度について図 1 亿示した。

疾患別に「効果あり」と回答（複数回答可）した CAM の種類を図 2 に示した.

患者が「効果あり」と回答した具体的内容については 図3 に示した.

次に患者の介護度と「あんま・マッサージ・指圧」の 効果については図 4 に示した。

西洋医学による医療とCAM を併用している患者で 
表 2 月 1 回以上利用する CAM の種類

\begin{tabular}{|c|c|c|c|c|}
\hline & \multicolumn{2}{|c|}{ 患者 } & \multicolumn{2}{|c|}{ 対照 } \\
\hline & $\begin{array}{l}\text { 月 } 1 \text { 以上利用 } \\
\text { する割合 }(\%)\end{array}$ & $\begin{array}{c}\text { 効果あり } \\
(\%)\end{array}$ & $\begin{array}{l}\text { 月 } 1 \text { 以上利用 } \\
\text { する割合 }(\%)\end{array}$ & $\begin{array}{c}\text { 効果あり } \\
(\%)\end{array}$ \\
\hline あんま・マッサージ・指压 & 60.8 & 51.3 & 32.4 & 62.8 \\
\hline 鍼众 & 30.9 & 32.4 & 14.1 & 29 \\
\hline 柔道整復 & 18.8 & 26.8 & 14.2 & 37.6 \\
\hline 漢方 & 31.8 & 42.2 & 17.4 & 35.3 \\
\hline 健康補助食品 & 40.5 & 25.8 & 42.5 & 35.9 \\
\hline
\end{tabular}

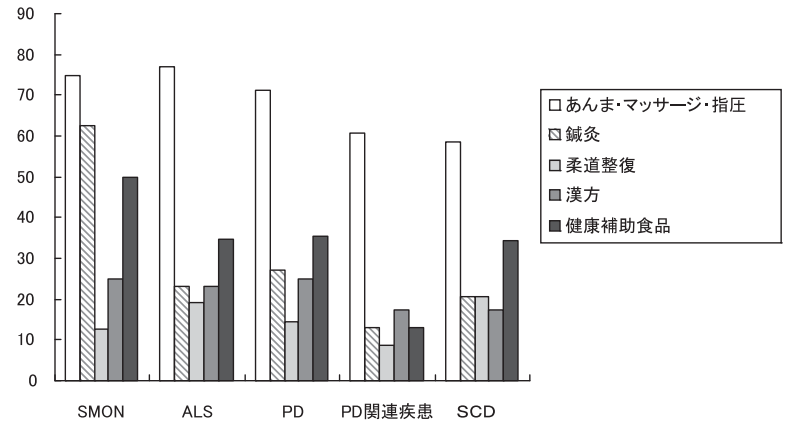

図 1 疾患別 $\mathrm{CAM}$ の利用状況の比較

スモン, ALS, パーキンソン病, パーキンソン病関連疾患, 脊 䯣小脳変性症の全てで，「あんま・マッサージ・指压」の利用が 最も多かった，スモンでは次に「銊尒」の利用が多いことが特 徵であった. ALS, パーキンソン病，パーキンソン病関連疾患， 脊䯣小脳変性症では，「あんま・マッサージ・指压」の次に「健

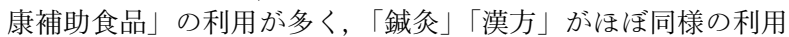
頻度であった. SMON : スモン, ALS : 筋萎縮性側索硬化症, $\mathrm{PD}$ : パーキンソン病, $\mathrm{SCD}$ : 春髄小脳変性症.

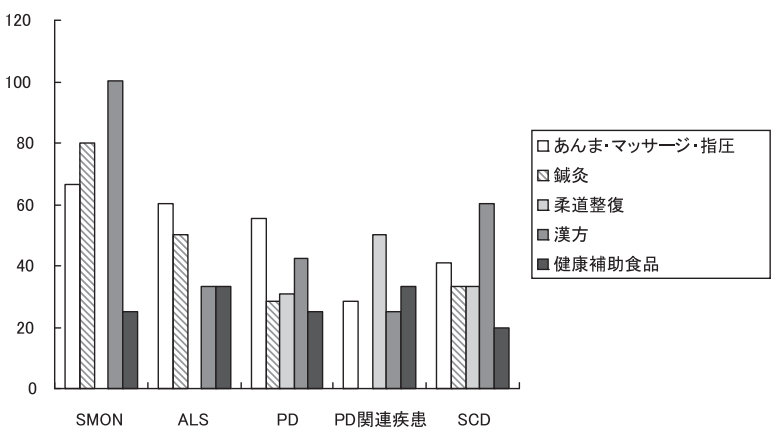

図 2 疾患別「効果有り」と回答した CAM の割合 スモンでは回答者全員が「漢方」は有効と回答した，ALS では 「あんま・指圧・マッサージ」が 60\%，「鍼尒」は $50 \%$ で効果 あり」と回答したが，「漢方」や「健康補助食品」では $33 \%$ に とどまった。 パーキンソン病では $55 \%$ の患者が「あんま・指压・ マッサージ」，42\%の患者が「漢方」は「効果あり」と回答し た。 パーキンソン病関連疾患では，50\%の患者が「柔道整復」 は「効果あり」と回答した. 脊髄小脳変性症では「漢方」が最 も「効果あり」とされ，次いで「あんま・指圧・マッサージ」 の順であった. SMON : スモン, ALS : 筋萎縮性側索硬化症, $\mathrm{PD}$ : パーキンソン病, $\mathrm{SCD}$ : 春髄小脳変性症.

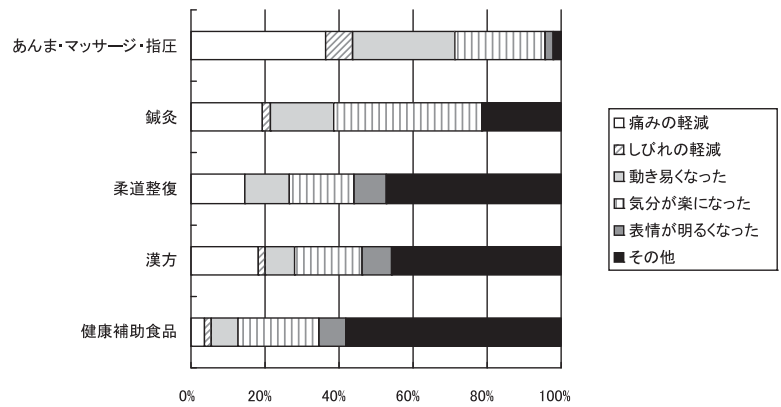

図 3 患者が「効果有り」と回答した効果の内容 「あんま・指圧・マッサージ」では，「痛みが軽くなった」が 36.2 $\%$ と最も多く，次いで「動き易くなった」 $27.7 \%$ ，「気分が楽に なった」24.5\%等であった。「銊尒」では，「気分が楽になった」 が 40.4\% と最も多く，次いで痛みの軽減（19.1\%）や動き易さ (17.0\%) に効果があると回答された。「柔道整復」，「漢方」，「健 康補助食品」では，選択肢以外の「その他」がそれぞれ 47.1\%, 46.0\%， 58.2\%等となっていた.

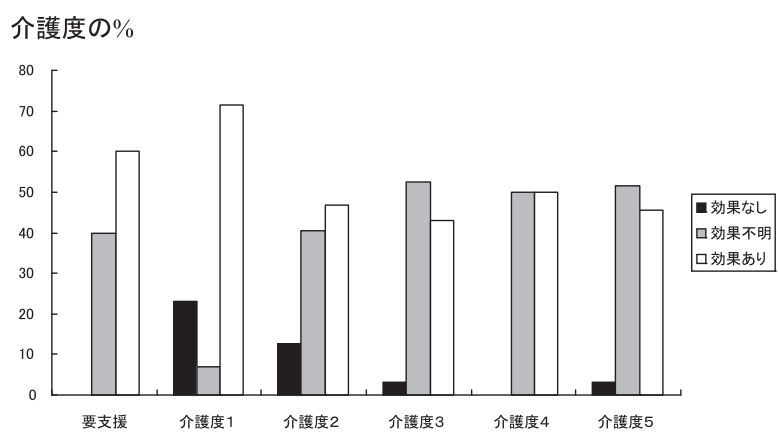

図 4 介護度と「あんま・マッサージ・指圧」の効果 患者の介護度と「あんま・マッサージ・指压」の効果について 示した．要支援と介護度 1 の患者では「効果あり」と回答する 者が 60-70\% と高く，一方介護度 3-5 では「効果あり」との回 答は平均 $46 \%$ に止まり，「効果不明」とする者が約半数であっ た。 
は, CAM 利用について主治医に相談した者 $50.2 \%$, 相 談していない者 49.8\%であった。

\section{CAM の利用と全般的健康感について一患者と対照の 比較}

「あんま・マッサージ・指圧」の利用割合は，神経難病

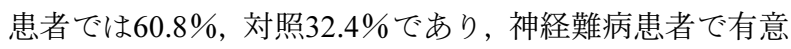
に多かった $(\mathrm{p}<0.05)$ （表 2)，CAM の利用頻度の最も高 かった「あんま・指圧・マッサージ」について効果と健 康感の関連を検討した。「あんま・指压・マッサージ」の 「効果あり」と回答した神経難病患者のらち 66\% 沶い て, 全般的な健康状態が「病状は落ち着いており気分が 良い・気分はまあ良い」と回答し，これは「良くない・ あまり良くない」と回答した患者割合に比し有意に多 かった $(\mathrm{p}<0.05)$ (表 3). パーキンソン病患者に限っても, 「効果あり」と回答した患者のらち $65.2 \%$ が病状は落ち 着いて打り気分が良い・気分はまあ良い」と回答し，「あ まり良くない・良くない」と回答した患者割合 $34.8 \%$ に 比し有意に多かった $(\mathrm{p}<0.05)$ （表 3)，さらに，「あんま・ マッサージ・指圧」に「効果あり」と回答した患者では, 患者全体での「現在の全般的な健康状態が良い・まあ良 い」の割合 $55.3 \%$ に比べても高く, 対照の $63 \%$ とほぼ同 様であった（表 1）。患者では,「あんま・マッサージ・ 指圧」について,「効果の有無」と「全般的な健康状態の 良しあし」との間にゆるい正相関を認めた（Spearman 相 関係数 $0.205, \mathrm{p}=0.005)$. 一方，対照では，「あんま・マッ サージ・指圧」の効果と「現在の全般的な健康状態の良 しあし」には有意な相関を認めなかった。

一方利用割合が 2 番目に多かった「健康補助食品」の 効果については，69.9\%の患者が「効果不明」と回答し た. 主観的健康感と「健康補助食品」, 「漢方」,「鍼尒」, 「柔道整復」の各々の効果の有無に関して有意な相関関係 を認めなかった。
最近一年間の患者の健康状態の変化と「あんま・指圧・ マッサージ」の利用頻度を比較した．利用患者では 1 年 前と比較して漠然とした体の不調が増えた者の割合 73.8 \%で，病状悪化したと回答した者の割合 69.7\%であった が，一方非利用患者でも体の不調が増えたと回答した者 の割合 $67.8 \%$ ，病状悪化したと回答した者の割合 $62.4 \%$ であり，両者に有意差を認めなかった。最近一年間の漠 然とした体の不調の増加や，「病状悪化した」と感じたこ とと「あんま・指圧・マッサージ」の利用頻度とは関連 が認められなかった.

「鍼炎」,「柔道整復」の利用は患者, 対照で有意差を認 めず，「効果あり」の割合も患者と対照で有意差を認めな かった.「漢方」の利用は患者で対照に比し多い傾向で, 「効果あり」の回答は対照に比し患者の方が多い傾向で あったが有意差を認めなかった、「健康補助食品」の利用 割合は患者，対照でほぼ同数で，「効果あり」の回答に有 意差を認めなかった（表 2）。

\section{考察}

本研究では, 神経難病患者の CAM 利用実態を把握す ることを第一の目的にした。 また，神経難病に対する CAM の作用機序が必ずしも明らかでないため，本研究 では患者の自覚的有効性と全般的健康感を CAM の評価 に使用した.

本研究による回答率から換算した CAM の利用割合 は，神経難病患者では 20.5\%，対照では 9.8\%（それぞれ 回答者の約 $60.8 \% ， 30.2 \%$ ）と推察された。本研究の結 果からは，神経難病患者に打いて，対照に比し有意差を もって効果のある CAM は認められなかったが，神経難 病患者では,「あんま・マッサージ・指圧」が最も利用さ れ，症状緩和や全般的健康感（気分が良いといら状態） の向上に効果があると考えられた。

表 3 「あんま・マッサージ・指圧」の効果と主観的健康感

\begin{tabular}{|c|c|c|c|c|c|}
\hline & & \multicolumn{3}{|c|}{ 健康状態 } & \multirow{2}{*}{$\begin{array}{c}\chi 2 \text { 乗検定 } \\
\text { (Fisher 直接法) }\end{array}$} \\
\hline & & $\begin{array}{l}\text { 良い・・ } \\
\text { まあ良い }\end{array}$ & $\begin{array}{c}\text { 良くない・ } \\
\text { あまり良くない }\end{array}$ & 合計 & \\
\hline \multirow[t]{3}{*}{ 全患者 } & 効果あり & 64 & 33 & 97 & $\mathrm{p}<0.05$ \\
\hline & 効果なし & 10 & 10 & 20 & \\
\hline & 効果不明 & 30 & 40 & 70 & \\
\hline \multirow[t]{3}{*}{ パーキンソン病患者 } & 効果あり & 45 & 24 & 69 & $\mathrm{p}<0.05$ \\
\hline & 効果なし & 8 & 5 & 13 & \\
\hline & 効果不明 & 19 & 27 & 46 & \\
\hline \multirow[t]{3}{*}{ 対照 } & 効果あり & 57 & 30 & 87 & $\mathrm{p}<0.05$ \\
\hline & 効果なし & 4 & 9 & 13 & \\
\hline & 効果不明 & 20 & 18 & 38 & \\
\hline
\end{tabular}


これまで神経難病患者に打いて CAM 利用と主観的効 果について検討した研究は極めて少ない，パーキンソン 病患者に拈けるCAM の普及の実態を調査した大越らの 報告によると, 運動療法・理学療法を実施している患者 は 55\%であり，一方漢方薬の服用 $11.7 \%$ ，鍼尒 $3.3 \%$ ， あ んま・マッサージ治療 $11.7 \%$ などとされている22. 日本 神経内科専門医を対象としたアンケート調査では, 76.4 \%の医師がパーキンソン病患者に運動療法・理学療法を 実施し，さらに $29.8 \%$ の医師があんま・マッサージ治療 の紹介あるいは推奨，14.7\%で鍼炎治療の紹介・推奨, 5.9\%で漢方薬の処方が行なわ机ていた22). このよらに, パーキンソン病に対するあんま・マッサージ療法は比較 的多く，主に自覚的改善を目的として利用されている. これは, 本研究とほぼ同様の結果と考光られた。

本研究に打いて, 神経難病患者では「あんま・マッサー ジ・指圧」, 「健康補助食品」,「漢方」の利用割合が多く, 自覚的効果も高かった。 さらに, 一一年前に比して病状が 進行・悪化している」かどらかとは関係なく，「全般的健 康感」改善に有効であったことから，CAM 療法は神経 難病患者の症状緩和に有効と考元られた。今後, 客観的 効果判定と作用機序の解明が課題と考兄られる. また本 調査から，我が国では主治医に相談せずに CAM を利用 している患者が約半数いることが明らかになった．患者 が主治医に CAM 利用に関して躊躇無く相談できるため にも，一般人のみならず医療関係者についても CAM の 理解と普及の啓発活動が必要と考えられた。

文献的には, 癌患者を対象とした CAM 研究が多く, 米国, 英国, ドイッなぞでは癌患者の 40-60\%で CAM の 利用が報告されている3,4)。これらの国では，CAM に関 する各種データベース作成や研究機関・研究者間ネット ワーク構築が進められ, さらに癌患者向けの CAM 指導 書の提供など積極的な研究と啓発がなされている. 英国 では，癌患者のペインコントロールのため，医師の約 70 \%が鍼众治療を利用しているとされ，その他マッサージ やアロマテラピー，リフレクソロジーなぞも 70-80\%の 臨床現場で活用が報告されている，日本においては，癌 患者の $44.6 \%$ が 1 種類以上の CAM を利用していること が示され，また，日本の特徵として健康食品の利用頻度 が 96.2\%と極めて高いことが指摘されている は癌の進行抑制，症状緩和などの他，生活習慣病，アレ ルギー, 感染症, 自己免疫疾患など広い領域にわたって 効果が期待されている6 ${ }^{6}$. さらに, 健康成人に打けるマッ サージ療法の効果の検討では, 不安の軽減効果, 免疫力 および血清脂質濃度に影響を与えることが示されている 7). 今後, 神経疾患に打いても疾患別にCAM の効果を自 覚的のみならず科学的に実証していく必要がある.

\section{結論}

本研究では, 回答率から換算した CAM の利用割合は

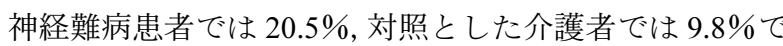
あった．患者に利用されている CAM の内訳は，「あん ま・マッサージ・指圧」が $60.8 \%$ と最も多く，次いで「健 康補助食品」 $40.5 \%$ ，「漢方」 $31.8 \%$ であり，自覚的な症 状緩和や全般的健康感（気分が良いといら状態）の向上 に有効と考兄られた，神経難病患者では，「鍼炎」や「柔 道整復」の利用割合はそれぞれ $30.1 \% ， 18.8 \%$ と多くは なかったが，利用者では効果ありの回答が多い傾向を認 めた．さらにCAMの「効果あり」と回答した患者では, 主観的健康状態が良好と感じている者が多かった．根治 療法が未だ確立されていない疾患を有する患者に打い て，CAM が症状緩和に有効との結果が得られたことか ら，神経難病患者の身体的及び精神的な負担の軽減に対 し CAM の利用が選択肢の一つとして有用性を示すもの

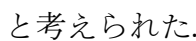

\section{助成源}

研究資金の一部は厚生労働科学研究費難治性疾患克服 研究事業スモンに関する調査研究班，同特定疾患の疫学 に関する研究班から助成を受けた。

\section{参 考 文 献}

1) Eisenberg DM, Davis RB, Ettner SL, et al. Trends in alternative medicine use in the United States, 1990-1997: results of a follow-up national survey. JAMA 1998; 280: 1567-1575.

2) 大越教夫。パーキンソン病に扮ける補完代替医療に関する 実施状沉一患者および神経内科専門医に対するアンケート 調查一。筑波技術大学テクノレポート．2007; 14: 207-210.

3) Hyodo I, Amano N, Eguchi K, et al. Nationwide survey on complementary and alternative medicine in cancer patients in Japan. Journal of Clinical Oncology 2005; 23: 2645-2654.

4) 大野 智, 鈴木信孝, 井上正樹. がんの補完代替医療 (1). 綜合臨牀．2005; 54(10): 2765-2771.

5) 兵頭一之介. 癌の補完代替医療. 日本補完代替医療学会誌 2004; 1: 7-15.

6) 伊藤寿記，甲斐康之，井倉 技ら．補完医療と粘膜免疫一 炎症性腸疾患の最近の話題一. 日本補完代替医療学会誌. 2008; 2: 85-101.

7) 栗山洋子, 渡辺総子, 忠井俊明ら. 成人被験者に対するマッ サージの免疫学的, 血液学的, 心理学的効果. 日本補完代 替医療学会誌. 2005; 2: 59-65. 綜合臨牀. 2005; 54(10): 27652771. 


\author{
ABSTRACT \\ Use of Complementary and Alternative Medicine by Intractable Neurodegenerative \\ Patients and Caregivers \\ Tameko KIHIRA $^{1}$, Kazushi OKAMOTO ${ }^{2}$, Sohei YOSHIDA ${ }^{1}$, Ikuro WAKAYAMA ${ }^{1}$, Noboru KIBI ${ }^{3}$ \\ ${ }^{1}$ Department of Health Sciences, Kansai University of Health Sciences \\ ${ }^{2}$ Department of Public Health, Aichi Prefectural College of Nursing and Health, Nagoya \\ ${ }^{3}$ Department of Acupuncture and Moxibustion, Kansai University of Health Sciences
}

Objective: We aimed to characterize patterns of use of complementary and alternative (CAM) therapies on patients with intractable neurodegenerative diseases and their caregivers.

Methods: We sent questionnaires to 1,406 patients with subacute myelo-optico-neuropathy (SMON), amyotorophic lateral sclerosis (ALS), Parkinson's disease (PD), Parkinson related disease, or spino-cerebellar degeneration (SCD). We also send questionnaires to the 1,406 caregivers of these patients. The participants were asked to answer questions about current use of Annma/Massage/ Shiatu, acupuncture, Zyudoseifuku, Chinese medicine or Supplementary food. Other questions including reasons for the use, subjective effectiveness of the CAM and subjective wellness were also asked.

Results: $33.7 \%$ of patients and $30 \%$ of caregivers responded to the questionnaires. Anna/Massage/Shiatu and Chinese medicine were most frequently used by patients $(60.8 \%)$, and $51.3 \%$ of them answered that these therapies were effective. The caregiver's response showed supplementary food and Anna/Massage/Shiatu were most frequently used (42.5\%), and $35.9 \%$ of them answered that these were effective.

Conclusion: The present study showed that use of CAM was $20.5 \%$ in patients with intractable neurodegenerative diseases and $9.8 \%$ among caregivers when calculated using collection rates. Annma/Massage/Shiatu was most frequently used and was regarded effective on subjective wellness both in the patients and caregivers.

Key words: Patients with neurodegenerative disease, Parkinson's disease, usage, caregivers 